\title{
Article
}

http://dx.doi.org/10.11646/phytotaxa.205.3.2

\section{The circumscription of problematic species of Ophioglossum (Ophioglossaceae) from Southern South America: a palynological approach}

\author{
ESTEBAN I. MEZA-TORRES ${ }^{1}$, CARMEN C. MACLUF², MARTA A. MORBELLI ${ }^{2} \&$ MARÍA S. FERRUCCI $^{1}$ \\ 1. Instituto de Botánica del Nordeste, (CONICET - UNNE), Sgto. Cabral 2131, C.C. 209. 3400 - Corrientes, Argentina. \\ E-mail:mezatorresii@yahoo.com.ar \\ 2. Cátedra Palinología, Facultad de Ciencias Naturales y Museo, UNLP, $64 N^{\circ} 3$ (1900), La Plata, Argentina
}

\begin{abstract}
The genus Ophioglossum has around 25 species with a nearly cosmopolitan distribution. It has historically posed a number of taxonomic problems due to the lack of morphological characters upon which to base species delimitations. In order to address this, we analyzed the sculpture patterns of spores from ten critical taxa from southern South America. Palynological data was compared with the morphology of the sporophyte. The sculpturing pattern was the most valuable and consistent taxonomic character upon which to base species delimitation in Ophioglossum. Nomenclatural types of studied species were examined. The name Ophioglossum melipillense is reinstated and the other species recognized to the genus Ophioglossum s.s. in this region are the following: O. crotalophoroides, O. nudicaule, O. opacum, and O. vulgatum. Ophioglossum fernandezianum appears to be a doubtful species. Ophioglossum lusitanicum is excluded from the study area, but the lectotype of O. lusitanicum is designated, and a revised synonymy is presented.
\end{abstract}

\section{Resumen}

El género Ophioglossum cuenta con alrededor de 25 especies y presenta distribución casi cosmopolita. Históricamente se han planteado numerosos problemas taxonómicos debido a la falta de caracteres morfológicos sobre los cuales basar la delimitación de las especies. Para hacer frente a esto, se analizaron los patrones de escultura de esporas de diez taxones críticos en el género Ophioglossum del Cono Sur de América. Los datos palinológicos se compararon con la morfología de la esporofito. El patrón de la escultura fue un carácter taxonómico muy valioso y consistente sobre la cual basar la delimitación de las especies. Se examinaron los tipos nomenclaturales de las especies estudiadas. Se restablece el nombre Ophioglossum melipillense y para el área de estudio se reconocen las siguientes especies para género Ophioglossum s.s.: O. crotalophoroides, O. nudicaule, O. opacum, O. vulgatum y el nombre O. lusitanicum es excluido. Ophioglossum fernandezianum es considerada una especie dudosa. Se examinan todos los tipos nomenclaturales de las especies estudiadas, se designa el lectotipo de Ophioglossum lusitanicum y se presentan nuevas sinonimias.

Keywords: Linnaean species; ophioglossoid species; palynology, southern South America; spores; typification

\section{Introduction}

The genus Ophioglossum was described by Linnaeus (1754: 484), and probably has 20-25 species worldwide (Mickel $\&$ Smith 2004). It occurs mostly in disturbed, open and grassy habitats and is often overlooked because of superficial resemblance to seedlings of monocotyledonous plants (Wagner \& Wagner 1993). This genus has historically posed a number of problems for taxonomists because of the lack of morphological characters upon which to base species delimitations. Its simple structure and presumed variation within a species has resulted in many distinct taxa being lumped in large 'traditional' species complexes due mainly to an insufficient characters with which to set them apart (Burrows, 1997). Burrows (1997) found that the spore morphology provided the most consistent taxonomic character upon which to delimit most species. In an effort to find other diagnostic characters, several taxonomists working in this family focused on the ornamentation of the spore walls to complement their systematic studies (e.g.: Burrows 1997, Burrows \& Edwards 1993, 1995; Uehara \& Kurita 1989).

A world-wide revision of Ophioglossaceae was conducted by Clausen (1938), and the species from southern 
closely related taxa Africa, Asia, Australasia, North and South America would be required to revise species delimitation in the genus Ophioglossum.

\section{Acknowledgement}

This study was possible thanks to doctoral grants from CONICET. All directors and curators from the various herbaria cited in this paper are thanked for allowing to examine their material, especially Mia Ehn and Jens Klackenberg (S), Alison Paul and Jovita Yesilyurt (BM), Nicolas Fumeaux (G) and Germinal Rouhan (P). We also thank Ewen Cameron and Geoff Davidson from the Auckland Museum, for providing specimens from the Cook Islands; Michael Sundue and Mararten Christenhusz for correcting the English in this manuscript, and for their valuable comments. Antonio Krapovickas is acknowledged for making valuable taxonomic suggestions. Financial support for our research was provided by Myndel Botanical Foundation and by the Universidad Nacional del Nordeste (SGCyT-UNNE. PI N ${ }^{\circ}$ A012-2013).

\section{References}

Barrelier, J. (1714) Plantae per Galliam, Hispaniam et Italiam observatae, iconibus aeneis exhibitae a R. P. Jacobo Barreliero, opus posthumum editum Antonio de Jussieu. S. Ganeau, Paris, xv +140 pp. +144 plates.

Burrows, J.E. (1997) The use of spore morphology as a taxonomic tool in the delimitation of the southern Africa species of Ophioglossum L. (Ophioglossaceae: Pteridophyta). In: Johns, R.J. (Ed.) Holttum Memorial Volume. Royal Botanical Garden, Kew, pp. 43-65.

Burrows, J.E. \& Edwards, T.J. (1993) Nomenclatural changes and additions to the genus Ophioglossum in Africa (Ophioglossaceae: Pteridophyta). Bothalia 23: 185-190.

Burrows, J.E. \& Edwards, T.J. (1995) A new species and a change of status in Ophioglossum (Ophioglossaceae: Pteridophyta) in Africa. Bothalia 25: 61-63.

Carmichael, D. (1819) Some accounts of the Island of Tristan da Cunha and of its natural productions. Transactions of the Linnean Society of London 12: 483-513.

Christensen, C. \& Skottsberg, C. (1920) The pteridophyta of the Juan Fernandez Islands. The Natural History of Juan Fernandez and Easter Island 2: 1-46.

Clausen, R.T. (1938) A monograph of the Ophioglossaceae. Memoirs of the Torrey Botanical Club 19: 1-177.

Clausen, R.T. (1949) The Ophioglossum of the Falkland Islands and the relationships and distribution of Ophioglossum crotalophoroides. American Fern Journal 38: 176-186.

Colla, A. (1836) Herbarium Pedemontanum juxta Methodum Naturalem Dispositum Additis nonnullis stirpibus exoticis ad universos ejusdem methodi ordines exhibendos, vol. VI. Printed for the King, Turin, $606 \mathrm{pp}$.

Cunningham, A. (1837) Florae insularum Novae Zealandae precursor; or a specimen of the botany of the islands of New Zealand. Companion to the Botanical Magazine 2: 358-378.

De la Sota, E.R. \& Ponce, M.M. (2008) Ophioglossaceae. In: Zuloaga, F.O., Morrone, O. \& Belgrano, M.J. (Eds.) Catálogo de plantas vasculares del Cono Sur (Argentina, Sur de Brasil, Chile y Uruguay (1). Monographs in systematic botany from the Missouri Botanical Garden 107. Missouri Botanical Garden Press, St. Louis, pp. 99-101.

Eaton, D.C. (1860) Cryptogamous or flowerless plants. In: Chapman, A.W. (Ed.) Flora of the southern United States, Ivison, Phinney \& Co., New York, pp. 585-602.

Gay, C. (1853) Historia fisica y politica de Chile según documentos adquiridos en esta republica durante doce años de residencia en ella y publicada bajo los auspicios del supremo gobierno. Botánica, tomo VI, E. Thunot, Paris, 479 pp.

Heusser, C.J. (1971) Pollen and spores of Chile: modern types of the Pteridophyta, Gymnospermae, and Angiospermae. University of Arizona Press, Tucson, 167 pp.

Hooker, W.J. \& Arnott, G.A.W. (1832) The botany of Captain Beechey's voyage. H. G. Bohn, London, ii +485 pp.

Hooker, W.J. \& Greville, R.K. (1831) Icones filicum ad eas potissimum species illustrandas destinatce, Vol. I. Treuttel \& Würtz, London, cxx plates.

Lichtenstein, J.S. (1944) Las Ofioglosáceas de la Argentina, Chile y Uruguay. Darwiniana 6: 380-441.

Linnaeus, C. (1753) Species plantarum. L. Salvius, Stockholm, 561-1200 pp.

Linnaeus, C. (1754) Genera plantarum. L. Salvius, Stockholm, xxxii + 500 pp.

Linnaeus, C. filius (1782) Supplementum plantarum systematis vegetabilium editionis decimae tertiae, generum plantarum editiones 
sextae, et specierum plantarum editionis decundae. Waisenhaus (Orphanotropheum), Braunschweig, $\mathrm{xv}+468 \mathrm{pp}$.

Meza Torres, E.I. (2012) Biosistemática de Ophioglossaceae Martinov (Pteridophyta) del Cono Sur de América. Análisis morfoestructural, sistemático y biogeográfico. Doctoral thesis, Universidad Nacional de La Plata, Argentina, iii +240 pp.

Meza Torres, E.I., De la Sota, E.R. \& Ferrucci, M.S. (2013A) Biogeographic analysis and key to the genera of ferns and lycophytes of Mburucuyá National Park, Corrientes, Argentina. Revista Chilena de Historia Natural 86: 49-61.

Meza Torres, E,I,, De la Sota, E.R. \& Ferrucci, M.S. (2013B) Sinopsis de los helechos y licofitos del Parque Nacional Mburucuyá (Corrientes, Argentina). Claves de especies. Boletín de la Sociedad Argentina de Botánica 48: 121-136.

Mickel, J.T. \& Smith, A.R. (2004) The pteridophytes of Mexico. Memoirs of the New York Botanical Garden. 88: 1-1055.

Michaux. A. (1803) Flora Boreali-Americana. Levrault, Parisis, $\mathrm{x}+330 \mathrm{pp}$.

Morbelli, M.A. (1978) Key to the genera of Pteridophyta of Fuego-Patagonia. In Markgraf, V. \& D’Antoni, H.L. (Eds.) Pollen flora of Argentina. The University of Arizona Press, Tucson, pp. 125-128.

Morbelli, M.A. (1980) Morfología de las esporas de Pteridophyta presentes en la región Fuego-Patagónica, República Argentina. Opera Lilloana 28: 11-95.

Morbelli, M.A. (1983) Estudios de las esporas de las Pteridofitas del Noroeste de Argentina. Ophioglossaceae. Physis (Buenos Aires), secc. C. 41: 131-150.

Murillo, M.T. \& Bless, M.J. (1974) Spores of recent Colombian pteridophyta. I. Trilete spores. Review of Palaeobotany and Palynology 18: 223-269.

Philippi, R.A. (1865) Plantarum novarum Chilensium centuriae, inclusis quibusdam Mendocinis et Patagonicis. Linnaea 33: 1-308.

Prantl, K. (1883) Systematische Uebersicht der Ophioglossen. Berichte der Deutschen Botanischen Gesellschaft 1: 348-353.

Punt, W., Hoen, P.P., Blackmore, S., Nilsson, S. \& Thomas, A.L. (2007) Glossary of pollen and spore terminology. Review of Palaeobotany and Palynology 143: 1-81.

Smith, J. (1875) Historia filicum. Macmillan \& Co., London, xiv + 429 pp.

Stafford, P.J. \& Paul, A.M. (2008) The Northwest European pollen flora, 69 Ophioglossaceae. Review of Palaeobotany and Palynology 157: 2-21.

Tryon, A. \& Lugardon, B. (1991) Spores of the Pteridophyta. Surface, wall structure and diversity based on electron microscope studies. Springer-Verlag, New York. Xii + 648 pp.

Uehara, K. \& Kurita, S. (1989) Ultrastructure study of spore wall morphogenesis in Ophioglossum thermale Kom. var. nipponicum (Miyabe \& Kudo) Nishida. Botanical magazine, Tokyo 102: 413-427.

Wagner, W.H. Jr. \& Wagner, F.S. (1993) Ophioglossaceae. In: Flora of North America Editorial Commitdstee (Eds.) Flora of North America. 2. Pteridophyte and Gymnosperms. New York, pp. 85-106.

Walter, T. (1788) Flora Caroliniana. J. Fraser, London, viii +263 pp.

Ward, D.B. (2008) Thomas Walter typification project, VI: Neotypes for an additional 18 Walter names. Journal of the Botanical Research Institute of Texas 2: 1279-1283.

Zuloaga, F.O., Morrone, O. \& Belgrano, M.J. (Eds.) (2008) Catálogo de las plantas vasculares del Cono Sur (Argentina, Sur de Brasil, Chile, Paraguay y Uruguay). Vol. 1. Monographs in Systematic Botany from the Missouri Botanical Garden 107: 1-984. 